\title{
Boğaziçi'nin Avrupa Sahili'nde İnşa Edilmiş Kat Apartmanları ve Koruma Değerleri
}

\author{
First Appartment Buildings in European Side of \\ Bosphorus and Their Conservation Values
}

\author{
Ayşegül ORHAN ŞAHAN, @ Can Şakir BINAN
}

Öz

20. yüzyılın mimari miraslarından biri olduğu düşünülen kat apartmanları, II. Dünya Savaşı'ndan sonra ülkemizde yoğun bir şekilde inşa edilmiştir. Makalenin amacı, Boğaziçi'nin Avrupa Sahili'nde inşa edilmiş kat apartmanlarının korunmalarını gerektiren özel değerlerini belirleyerek, bu yapılar ile ilgili uzmanlar tarafından gerçekleştirilecek koruma çalışmalarına veri oluşturmaktır. II. Dunya Savaşı'ndan sonra ülkemizdeki toplumsal, sosyo-kültürel, ekonomik, mimari ve teknolojik gelişmeler ışığında şekillenen kat apartmanlarında; eski, tasarım, üslup, mimari müellif, eski strüktür-malzeme, standartlaşma, kişisel anı, konut stoğu, işlevsellik, çevresellik, grup-çokluk-homojenlik, kentsel kimlik özellikleri kültür varlıkları olarak korunmalarını gerektiren özel değerleri olarak belirlenmiştir. Kat apartmanlarının özel değerleri aracılığıyla ülkemizin sağlayacağı; mimari, kentsel, sosyo-kültürel ve ekonomik kazanımlar açıklanmıştır.

Anahtar sözcükler: 20. yüzyıl mimari mirası; Boğaziçi; kat apartmanları; koruma değerleri; modern mimari miras.

\section{ABSTRACT}

Apartments thought to be one of the architectural heritages of the $20^{\text {th }}$ century; it was built intensely in our country after World War II. The aim of the article is to establish the specific values that need to protect the apartments built on the European Coast of the Bosphorus and to create data for the conservation work to be carried out by experts on these buildings. After the World War II, in the floor apartments shaped by the social, socio-cultural, economic, architectural and technological developments in our country; old, design, style, traditional structure-material, standardization, personal memory, residential stock, functionality, environmentalism, group-plural-homogeneity and urban identity are required to be preserved as cultural assets. The architectural, urban, socio-cultural and economic gains that our country will provide through the special values of the apartment buildings are explained.

Keywords: $20^{\text {th }}$ century architectural heritage; Bosphorus; floor apartments; conservation values; modern architectural heritage.

Doğuş Üniversitesi Sanat ve Tasarım Fakültesi, Mimarlık Bölümü, İstanbul 


\section{Giriş}

İkinci Dünya Savaşı'ndan sonra ülkemizde ortaya çıkan ekonomik ve toplumsal hareketlilik, konut ihtiyacını ve dolayısıyla konut üretiminde artş̧ı beraberinde getirmiştir. Ancak bu dönemde ekonomik açıdan konut gereksinimini yasa ve kanunların gerektirdiği gibi tek parselde, tek ev olarak karşılama imkanı zorlaşmıştı. Bu nedenle tek parsel üzerinde birden fazla kişinin bir araya gelerek gerçekleştirdiği çok katlı konutlarda, birer kat sahibi olmak çözüm olarak görülmüştür. Her kat bir ya da daha çok sayıda bağımSIz daireye bölünerek inşa edildikleri için kat apartmanları olarak isimlendirilmiş çok katlı konutlar, kanunlardaki yeni düzenlemeler sonucunda kent merkezleri ile kentin yeni imara açılan alanlarında yer almıştır.

Ülkemizdeki yeni konut üretimini temsil eden katlı apartmanlaşma süreci İstanbul'da da yaşanmış, kat apartmanlarının modernist villalar ve ahşap konutlarla birlikte oluşturduğu yerleşimler ortaya çıkmıştır. İstanbul'da Boğaziçi'nin Avrupa Sahili, kat apartmanlarının en çok inşa edildiği bölgelerden bir tanesi olmuştur. İmar planlarının ve ulaşım projelerinin hız kazandığı yıllarda, Boğaziçi'ndeki nüfus artışını karşılamak için çok sayıda kat apartmanı inşa edilmiştir.

Makalede 1946-1966 yılları arasında inşa edilmiş kat apartmanlarının korunmalarını sağlayacak değerler incelenmiştir.Halen geçerli olan plan şartları sayesinde çok sayıdaki kat apartmanı korunduğu için Boğaziçi Bölgesi çalışma alanı olarak seçilmiştir. İncelenen dönem aralığı, yapılarda mülkiyet bölünmesini getiren yasal sürecin hazırlık evresi olan 1946 yılı ve kat mülkiyeti uygulamasının resmen uygulanmaya başladığı 1966 yılıdır.

\section{Boğaziçi'ndeki Kat Apartmanlarının Gelişim Süreci ve Mimarileri}

Yoğun yapılaşma süreci Boğaziçi Bölgesi'nde 19.yüzyılda başlamış, Cumhuriyet'in ilanı ile yavaşlamış daha sonra 1950'lerin toplumsal ekonomik koşullarına uygun dönüşüm özelliklerini taşıyarak sürmüştür. Bölgenin konut kimliği 15.yüzyıldan 20.yüzyılın ilk yarısına kadar kıyı boyunca sayfiye niteliğindeki yalılar, saraylar, köşkler ve kasırlardan oluşmuştur. Boğaz köyleri ise vadiler ve kıyılarda yer alan en eski yerleşim alanları olarak gelişimlerini sürdürmüşlerdir. Cumhuriyet'in ilanından sonra başkentin Ankara'ya taşınması ile Boğaziçi'ne olan ilgi azalmaya başlamışsa da ulaşım ağının genişlemesi ve yeni imar kararları bu bölgeye taleplerin sürekliliğini sağlamıştır. 1950'lerde Türk ekonomisindeki hareketlenme ile İstanbul başta olmak üzere Boğaziçi'nde de yapılaşma hız kazanmıştır. Kat apartmanları da bu süreçte ortaya çıkmış konut ihtiyacını karşılamaya yönelik yapılar olmuştur.

1930'lardan 1960'lı yıllara kadar yoğun kent ortamları yerine hala sayfiye niteliğini koruyan Boğaziçi'nde modern görünümlü villalar ve az katlı konutların geleneksel ahşap konutlarla birlikte oluşturduğu mahallelerde çok sayıda kat apartmanı inşa edilmiştir. Mimarileri de bu dönemin toplumsal ve ekonomik şartlarından etkilenmiştir.

Makalenin çalışma aralığı olan aynı yıllar ile ilgili Sibel Bozdoğan ve Bülent Özer'in görüşleri kat apartmanlarının mimari özelliklerini belirlerken önemli bulunmuştur. Örneğin; Sibel Bozdoğan, Boğaziçi'nde katlı konutların yapımının bahçe içinde villa benzeri mimarileri nedeniyle savunulduğunu ve bir üslup göstergesi olarak; doğaya, gün ışığına açık ve sağlıklı yaşama imkanı veren çok katlı konut mimarisinin ortaya çıktı̆̆ını söylemiştir. ${ }^{1}$ Boğaziçi'ndeki kat apartmanları da o dönemin yeni mimarlık anlayışına uygun olarak geniş bahçeler içinde, doğaya ve gün ışığına açık ve az katlı olarak inşa edilmişlerdir.

Bülent Özer ise, II. Dünya Savaşı'dan sonra Türkiye Mimarlık ortamında uzun yıllar hakim olan Alman etkisinin ortadan kalkması ile 1940-1948 yılları arasında eklektisist formasyonla yetişmiş mimarların mesnetsiz kaldıklarını ve yaşadıkları kararsızlıkların ürettikleri yapılara yansıdığını belirtmiştir. ${ }^{2}$ Bu doğrultuda dünyada geçerli olan modernist mimari etkiler yerel üslup özellikleri ile harmanlanarak Bülent Özer'in işaret ettiği eklektisist formasyonla yetişmiş mimarların beğenilerine göre kat apartmanlarının cephelerinde yeniden şekillenmiştir.

Modernist villalar ve kat apartmanlarının üretimi bir yandan devam ederken 1950'lerden itibaren i̇stanbul'da yaşanan nüfus değişiminin beraberinde getirdiği gecekondulaşma Boğaziçi'ni de etkisi altına almış ve kat apartmanlarının korunmaları zorlaşmıştır.

Boğaziçi' nde yaşanan gecekondulaşma, vb. olumsuzluklara karşılık olumlu bir durum olarak 1960'lı yıllardan itibaren Nazım İmar Plan Bürosu tarafindan Boğaziçi için çeşitli koruma kararları alınmaya başlanmıştı. Bu konu ile ilgili ortaya çıkan en önemli uygulama 1983 yılında Boğaziçi'nin korunması için hazırlanan 2960 Sayılı Boğaziçi Yasa'sıdır. ${ }^{3}$

Yasa'ya göre Boğaziçi alanı, "Kıyı ve Sahil Şeridi" ile "Ön Görünüm ve Etkilenme Bölgeleri" ne ayrılmıştır. Boğaziçi'nin tarihsel ve kültürel değerinin ve doğal güzelliğinin, kamu faydası göz önünde bulundurularak korunması ve geliştirilmesini amaçlayan, bu doğrultuda nüfus yoğunluğunu attrabilecek yapılanmaları sınırlayan imar uygulamaları düzenlenmiş ve yeni konut yapımı yasaklanmıştır. Tescilli olmayan konutların "yıkıldıkları an yeşil alan statüsü kazanmaları nedeniyle, Boğaziçi Öngörünüm Bölgesi'nde her türlü konut yapısının değer kazandığı bir süreç başlamıştır. Günümüzde halen uygulamada olan bu yasa aralarında kat apartmanlarının da bulunduğu mevcut konutların korunmasını teşvik etmiştir.

\footnotetext{
Bozdoğan, s. 2002, s. 235.

Özer, B., 1965, s. 74.
} 


\section{Boğaziçi’ndeki Kat Apartmanlarının Özellikleri}

Dünyada ve ülkemizde 20. yüzyıl mimarlık mirası örnekleri, üretim süreci ve mimari özellikleri açısından, 18 . veya 19. yüzyıl örneklerinden tamamen farklı özellikler göstermiş, dolayısıyla değer yargıları ve korunma süreçleri de bu değişimden etkilenmiştir.

Kat apartmanlarını koruma çalışmalarında, 1946-1966 yılları arasında yaşanan siyasal, ekonomik, sosyo-kültürel ve teknolojik değişimlerin insan yaşamına etkileri ve bu etkilerin mimari yansımaları üzerine gerçekleştirilen araştormalar önem kazanmıştır. Bu doğrultuda kat apartmanlarının tarihselliği, toplumsal yaşamdaki değişime etkisi, konut üretim biçiminin değişimindeki yeri, mimari özellikleri, toplumun bu yapılar ile ilgili anıları vb. konuların incelenmesi gerekmiştir.

Koruma ve tespit çalışmalarına yardımcı olması amacıyla makalede, kat apartmanlarının korunmalarını gerektiren nedenler, özel değerleri olarak açıklanmıştr. Günümüzde yeni değer oluşturma, kabul ettrime, süreçlerinin uygulamaya geçirilmesindeki konusundaki zorluklar nedeniyle kat apartmanlarının özel değerlerini Türkiye'de koruma ve belgeleme çalışmalarında kullanılan KTVK Kanunu'nda kullanılan mevcut değerler sistemi üzerinden açıklamak için Tablo 1 hazırlanmıştır.

2863 sayılı KTVK Kanunu'nda ${ }^{4}$ bir yapının kültür varlığı olarak tescil edilmesi için gerekli ölçütler 6 . ve 7. maddelerde tanımlanmıştır. Yasanın 6. madde 2. fikrasındaki tanıma göre taşınmazın mimari, tarihi, estetik, arkeolojik ve diğer alanlarda önem ve özelliğinin bulunması yeterli görülmüştür. 7. madde ve 2 . Fıkrada ise tespit çalışmalarında taşınmazın "tarih, sanat, bölge ve diğer" özelliklerinin de dikkate alınması gerektiği vurgulanmıştır. Tanımda yer alan "diğer" sözcüğünün içi "Korunması Gerekli Taşınmaz Kültür ve Tabiat Varlıkları'nın Tespit ve Tescili hakkında Yönetmelik" ler ${ }^{5}$ ile doldurulmaya çalışılmıştır. Yönetmeliğin, "tanımlar" ve "tespitlerde değerlendirme kıstasları" başIıkları altnnda strüktürel, dekoratif yapısal durum, malzeme yapım teknolojisi ve şekil ölçütleri yer almıştır.

Kanun ve yönetmeliklere ek olarak 20. yüzyılın mimari ve kültürel mirası ile ilgili yapılmış çalışmalarda öne çıkan "belge değeri, anı değeri, simgesel değer, ekonomik değer, işlevsel değer ölçütleri kat apartmanlarının değerlerini belirlerken çıkış noktası olmuştur.

Kat apartmanlarının özel değerlerini mevcut değerler sistemi üzerinden açıklayan Tablo 1'e göre, birinci sütunda günümüzde kuram ve kanunlarda kullanılan değerler yer alırken, ikinci sütunda mevcut değerlerle örtüşen ancak kat apartmanları için özelleşmiş değerler bulunmaktadır.

\footnotetext{
41983 tarih, 2863 sayılı KTVK Kanu- rekli Taşınmaz Kültür Varlıkları ve nu.

1987 ve 2012 tarihli Korunması GeSitlerin Tespit ve Tescili Hakkında Yönetmelikler.
}

Tablo 1. Kat apartmanlarının özel değerleri ${ }^{6}$

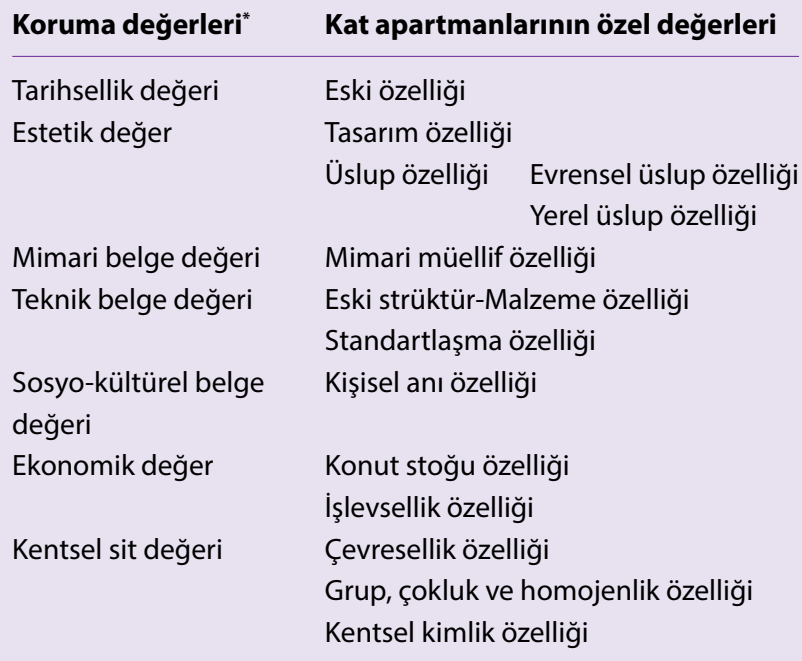

*Günümüzde kuram ve kanunlarda kullanılan değerlerden faydalanılmıştır.

\section{Eski Özelliği}

Kat apartmanlarının eski özelliği en genel anlamda; üretimlerinin başlaması ve bitmesi üzerinden belirli bir zamanın geçmesi olarak tanımlanmıştır. Polat, zamana bağlı bu özelliğin herkes tarafindan kolay algılandığını belirtmiștir. ${ }^{8}$ Bu nedenle eski özelliği, kat apartmanlarının da korunması gereken yapılar olmasının önünü açacak önemli bir özelliktir.

Ancak eski özelliği zaman zaman, günümüze çok yakın tarihlerde inşa edilmiş, korunması gerekli yapıların tescil edilmemesi gibi olumsuzluklara yol açmıştır. ${ }^{9}$

Ülkemizde sivil mimarlık eserleri olarak kabul edilen ahşap konut mimarisinin eskiliğinden kaynaklanan miras varlığı özelliği artkk tartışmasız herkes tarafindan kabul edilmiştir. 1920-25 yıllarında üretimleri biten ahşap konut mimarisinin, korunma sürecinin farkındalığı, 1930-1940'।ı yıllarda nitelikli ahşap yapıların tescil edilmesi ile başlamıştr. Bu farkındalık, ahşap konutların yok olmasının hızlandığı 1960-1970'li yıllarda giderek artmıştır. Günümüzde ise arthk hiçbir mimari özelliği olmasa dahi, bütün ahşap yapılar malzeme ve yapım sisteminden dolayı koruma altına alınmaktadır.

Ahşap konutların korunması için farkına varılma ve kesin bir şekilde miras olarak kabul edilme süreci ile kat apartmanları arasında benzer bir ilişki kurulduğunda, bu yapıların da günümüzde miras olarak kabul edilmesi gerektiği ortaya çıkmıştır. 1966 yılında üretimleri sona eren kat apartmanlarının, 1990'larda miras değerleri olduğunun

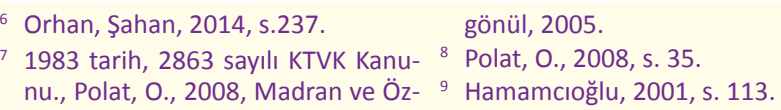



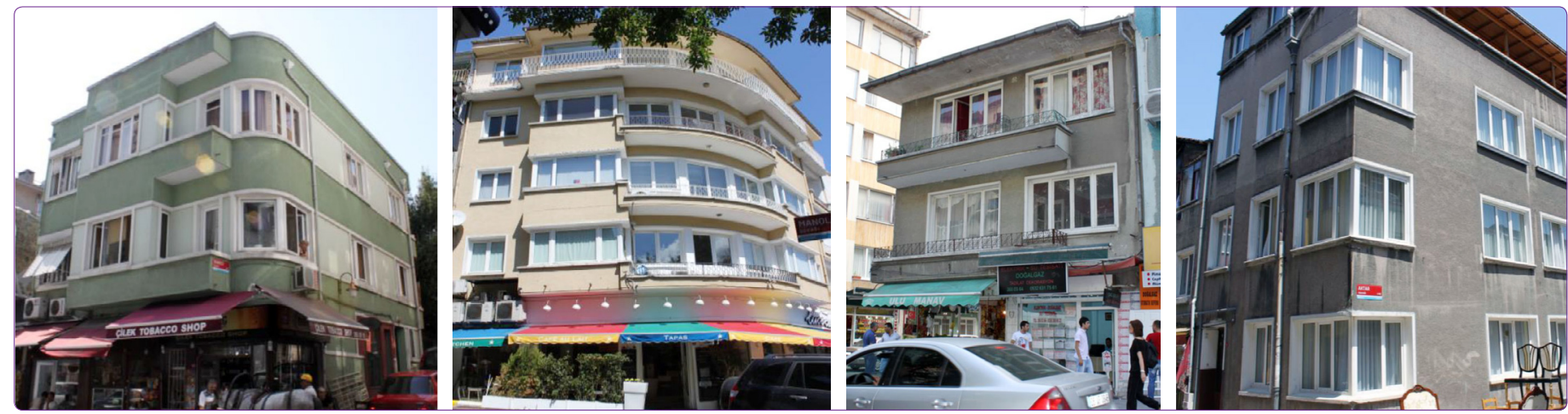

Şekil 1. Evrensel üslubun farklı örnekleri olan kat apartmanları.

farkına varılmış ve nitelikli örnekleri koruma altına alınmıştır. Sonrasında geçen 15-20 yıllık süreç kat apartmanlarının değer ve değer tanımlarının yapılıp korunmalarının kesinleşme sürecidir. Kat apartmanlarına eski özelliğini kazandırmaya olanak tanıyacak yeterli zaman dilimi geçmiştir. Geçen süreçte, bu konuyla ilgili yapılan bilimsel çalışmaların artmış olması da bu düşünceyi desteklemektedir.

\section{Tasarım (Estetik) Özelliği}

Nara Belgesi'nde (The Nara Document on Authenticity, ICOMOS-1994) tasarım özgünlüğünü belirleyen önemli faktörler olarak bulunduğu coğrafya ve iklime, yani çevreye ait tasarımlar gösterilmiştir. Nesnenin zaman ve yere bağlı özgünlüğü-biricikliği (authenticity), aynı zamanda nesnenin sanat yapıtı olma özelliği olmuş ${ }^{10}$ ve tasarım özelliği olarak değerlendirilmiştir. Yani biçim yerin ortamından doğmuyor, başka yer ve kültüre ait donmuş kodları tekrar ediyorsa, şimdiki zamanı reddetmektedir. ${ }^{11}$ Bu eklektisist durum da mimari tasarım sürecindeki en önemli problemdir.

Boğaziçi, kıyı bölgesi yerleşim özelliği gösteren bir alandır. Bu bölgede tespit edilmiş kat apartmanlarından, özellikle sahil bölgesinde inşa edilmiş olanlar, bölgenin coğrafi, iklimsel şartlarına göre inşa edilmiş olmaları ile bulundukları çevreye ait mimari özellik göstermiştir. Manzaraya yönelişleri, geniş teras ve balkonları, peyzajları vb. özellikleri kat apartmanlarını bulundukları coğrafyaya ait ve özgün hale getirmiş detaylardır.

\section{Üslup Özelliği}

Üslupsal özellikler, tasarım biçimlerini yansıtmak için kullanılan ve toplumda kabul görmüş tanımlardır. ${ }^{12}$ Kat apartmanlarının üslup özelliğini açıklamak için, Balamir ve Asatekin'in düşünceleri önemli bulunmuştur. Balamir ve Asatekin, 20.yüzyılda üretilmiş konutların üslup seçiminde, belirli bir kimlik iddiasıyla ortaya çıkmaktan çok, maddi koşulların ve kültürel alışverişin yönlendirdiği rastlantısal bir oluşuma dikkat çekmiştir. ${ }^{13}$

\footnotetext{
10 Jay, 1989'dan aktaran, Gökan, Yıldırım, Bostancıoğlu, Kasapoğlu, Düzgün, Öztürk, Uluca, Enginöz, 2001, s. 35.

poğlu, Düzgün, Öztürk, Uluca, Enginöz, 2001, s. 37.

12 Madran, 2009, s. 102

${ }^{11}$ Gökan, Yıldırım, Bostancıoğlu, Kasa- ${ }^{13}$ Balamir ve Asatekin, 1991, s. 79.
}

Dolayısıyla aynı dönemde, aynı bölgede birbirlerine çok yakın alanlarda farklı üsluplarda kat apartmanlarının ortaya çıkmasının nedeni, sosyo-kültürel ve ekonomik düzey çeşitliliğinin tasarıma yansıması olarak görülmüştür.

Dönemin ekonomik ve toplumsal şartlarının neden olduğu sosyo-ekonomik ikilemin yansıması en çok cephe özelliklerinde ortaya çıkmıştr. Özellikle cephe biçimlenişleriyle mimaride estetik değerlerin değişimini yansıtmış kat apartmanları, inşa edildikleri dönemin mimari özelliklerini tanımlayan yapılar olmuştur.Ülkemizde belli bir dönemin genelleşmiş konut estetiğini ortaya koyan üslup özelliği kat apartmanlarında; evrensel ve yerel üslup özellikleri olarak iki başılık altında incelenmiştir.

Yatay pencere ve denizlikler, söve ve köşe pencereleri, renkli sıvalı tarak mozaik binalar, yuvarlak köşeler, köşe dönen balkonlar, düşeyde vurgulanan sirkülasyon elemanları, parapet arkasında gizlenmiş çatılar, teras çatılar, plan şemasında cam bölme ile ayrılmış gerektiğinde büyüyebilen esnek mekanlar kat apartmanlarında gözlenen Avrupa'da üretilmiş yapılarla benzeşen evrensel usluba ait mimari özelliklerdir.

Diğer yandan kat apartmanlarının çoğunun mimarisi, taşıdığı yerel mimariye ait ögelerle Avrupa'da inşa edilmiş modern yapılardan farklılaşmıştır. Sosyo-kültürel faktörlerin şekillendirdiği biçimsel detaylar, kat apartmanlarının tasarımını kendi içinde de çeşitlendirmiş, Türkiye'ye özel, özgün yapmıştır. Yerel biçimlerin gözlendiği kat apartmanlarının bazıları geleneksel ahşap konut mimarisiyle benzeşirken, bazıları da Ali Cengizkan'ın dediği gibi; pastoral yaşant ortasındaki villa konutlar ile benzer görünümde inşa edilmişlerdir. ${ }^{14}$ Cephelerde yerel özellikler olarak geleneksel ahşap mimari ile benzeşen; simetrik tasarım anlayışı, cumbayı hatırlatan çıkmalar, çıkmaların altında ahşap payandaya benzer betonarme süs elemanları, saçak ve cephenin birleştiği yerde ve kat aralarında sıva profiller, tekrar eden dikdörtgen pencereler gözlenmiştir. Geniş saçakların alt bazen ahşap motiflerle süslenmiş, ahşap döşeme ki-

\footnotetext{
${ }^{14}$ Cengizkan, 2004, s. $115 . \quad{ }^{15}$ Orhan, Şahan, 2014, s. 248.
} 

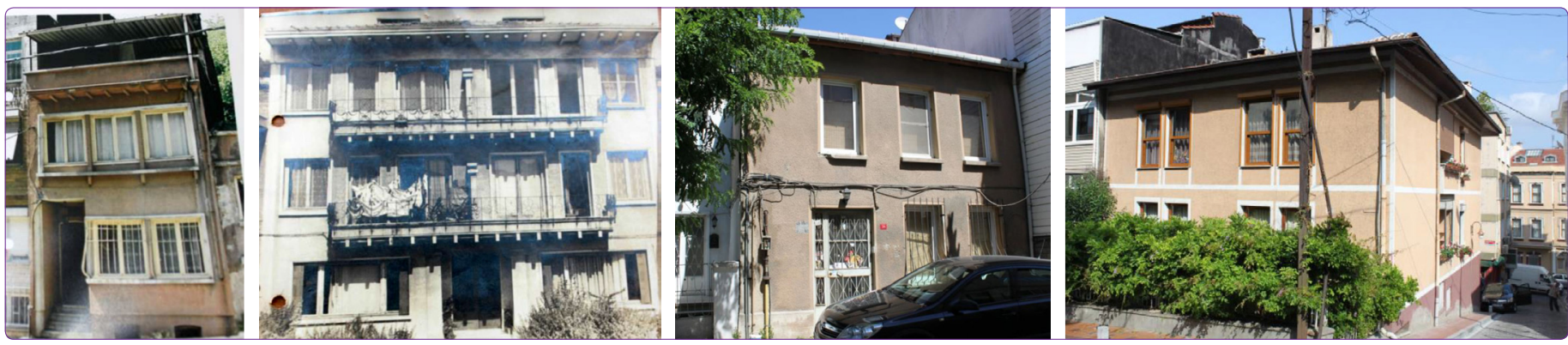

Şekil 2. Yerel üslupların farklı biçimlerini gösteren kat apartmanları. ${ }^{16}$

rişlerinin kopyaları olarak, betonarme kirişler saçaklardan taşırılmıştır (Şekil 1 ve 2).

\section{Mimari Müellif Özelliği}

Türkiye'de konutların koruma değerlerinin belirlenmesürecinde önem taşıyan bir diğer nokta da mimarlar tarafindan tasarlanmış olmalarıdır. Kat apartmanları, tasarımcıları ve tasarım süreçleri ile niteliksiz konutlardan farklılıklar göstermiştir. Belediye ve tapu arşivlerinden elde edilen projelerinden, kat apartmanlarının mimar ya da inşaat mühendisleri tarafindan projelendirilip, inşa edildikleri tespit edilmiştir.

Kat apartmanlarının hepsinin bir proje dahilinde mimar ve mühendisler tarafindan inşa edilmiş olması, konut mimarisinin söz konusu dönemde ve hemen öncesinde tasarımın ve tasarımcının önemini vurgulayan çalışmaların bir sonucu olarak ortaya çıktı̆̆ını göstermiş̧tir.

Ergut, koruma kanunlarında "tasarımcı" ya da "mimar" vurgusu yerine "ünlü mimar yapısı" olması üstüne yapılan vurguyu tasarım sürecinin ve tasarımcının varlığının dikkate alınmaması açısından eleştirmiştir. O'na göre; ... kanunda yazıldığı gibi bazı mimarları "önemli" diye ayırmak ve sadece onların ürettiği yapıları "değerli" görmek, yapılı çevrenin çok önemli bir kısmını feda etmek anlamına gelmektedir. ${ }^{17}$

\section{Eski Strüktür ve Malzeme Özelliği}

19. ve 20. yüzyılda, Avrupa ve Amerika ile kurulan ilişkiler sonucunda; ihtiyaç duyulan her türlü malzemenin sağlanması, pazar olma, düşünce üretimi ve uygulama alanlarında gelişme ve değişiklikler gözlenmiş, ${ }^{18}$ kat apartmanlarının mimarisi ve üretimi de bu süreçlerden farkIı şekilde etkilenmiştir. Bu yönleriyle kat apartmanları, Türkiye'de konut üretim süreci ve teknolojisinin farklılaşmasının belgeleri olarak kabul edilmiştir. Kat apartmanla$\mathrm{rl}$, sahip oldukları teknik ve malzeme özellikleri açısından konut üretim sürecinde yoğun olarak kullanılan ahşap malzemenin, kargire dönüşünün belgesidir. İnşa edildikleri dönemde, yeni strüktür sistemlerinin ve yeni malzemenin kullanıldığı yapılardır.

\footnotetext{
${ }^{16}$ Orhan, Şahan, 2014, s. 251 ve Boğaziçi İmar Müdürlüğü Proje Arşivi.

${ }^{17}$ Ergut, 2011, s. $114 . \quad{ }^{18}$ Cengizkan, 2011, s. 121.
}
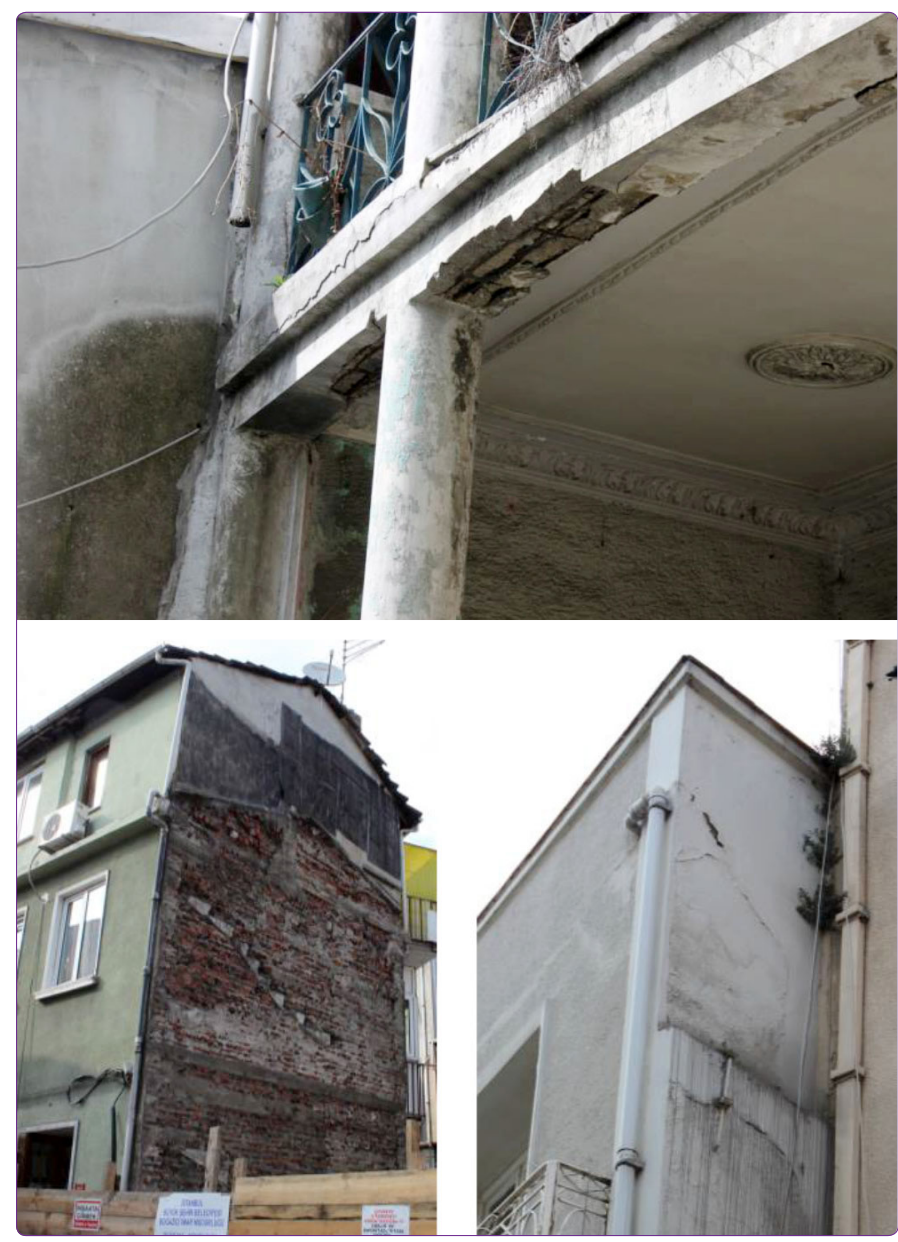

Şekil 3. Kat apartmanlarının yığma-betonarme karkas ve karma yapım sistemleri1. ${ }^{19}$

Kat apartmanlarının inşaatlarında geleneksel yapı malzemeleri olan taş, tuğla ve ahşabın yerini, çelik, cam ve betonarme almıştır. Daha önce kullanılmayan o dönem için yeni olan beton plak döşeme, yığma tuğla duvar ile karma sistem veya tamamen betonarme karkas sistem olarak inşa edilmişlerdir. Döşemeleri beton plak, duvarları tuğla yığma sistem olarak inşa edilen kat apartmanları günümüzde, bir dönem üretilmiş ve yok olmuş bir yapı türünün kalan örnekleridir (Şekil 3-5).

\footnotetext{
${ }^{19}$ Orhan, Şahan, 2014, s. 161.
} 


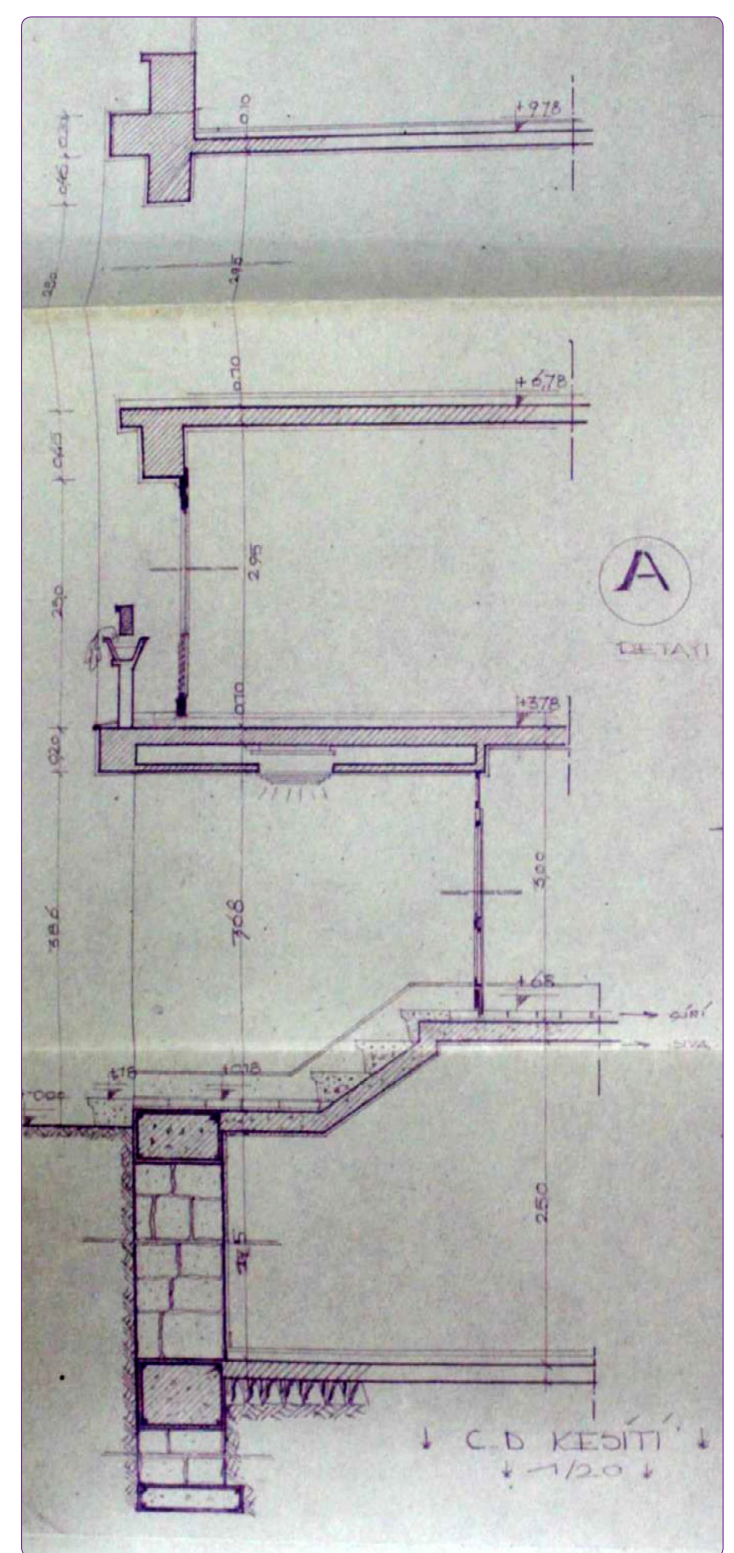

Şekil 4. Beşiktaş 198 ada/17 parsel'de bulunan yapının 1957 tarihli projesinde betonarme karkas sistem detayları. ${ }^{20}$

\section{Standartlaşma Özelliği}

20. yüzyılda yapı estetiğindeki değişimin rasyonel yanı nedeniyle giderek yaygınlaşan kullanımı, yapıların zamanla anonimleşmesini ve standartlaşmasını sağlamıştır. ${ }^{21}$

Gropius, standartlaşma sürecini olumlu yönleri ile değerlendirmiştir. Rasyonelleşme sürecinde eklektisizmden gerçek mimariye geçişte konut tasarımlarının standartlaşması ile ilgili görüşlerini: “...zaman, mekan, malzeme ve para faktörlerinin endüstri ve ekonomide hesaplı şekilde kullanılmaları bütün yapı organizmalarının çehrelerini belirleyen faktörleri önemli şekilde etkilemiş, sabit biçimlere, kalabalık içinde basitliğe, bütün yapı ünitelerinin, binala-

\footnotetext{
${ }^{20}$ Beşiktaş Belediyesi İmar Müdürlüğü Proje Arşivi. $\quad{ }^{21}$ Batur, 1998, s. 219.
}

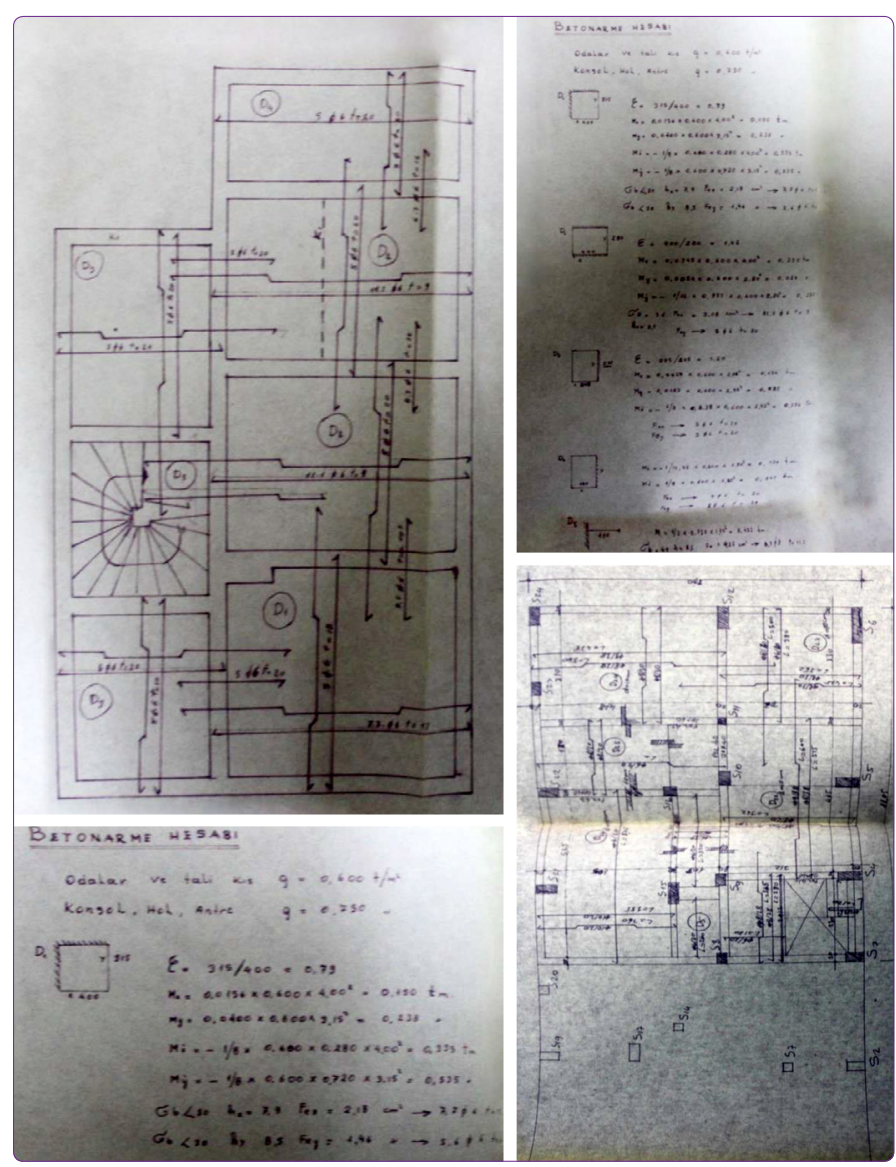

Şekil 5. Kat apartmanlarının betonarme projeleri ile temel ve kalıp planları. ${ }^{22}$

rın, caddelerin ve araçların fonksiyonlarına göre düzenlenmelerine, tipik formlara gidilmesine ve bu formların tekrarlanmasına yol açmıştır ..."şeklinde açıklamıştır. ${ }^{23}$

20.yüzyılda ülkemizde de, seri üretim ve standartlaşmaya imkan veren yeni teknoloji ve malzemelerin geliştirilmesi ile yapılaşmanın şartlarını belirleyen imar kanun ve yönetmeliklerin paralelinde, benzer boyutlardaki parsellerde benzer malzeme ve teknoloji ile inşa edilen kat apartmanları tekrarlanarak tipleşmiştir. Tip apartmanlar, tekrar ve uygulama kolaylığı sağlayan, benzer sorunlara benzer çözümler üretebilen rasyonel yapım sistemi ve standartlaşma özellikleri ile ön plana çıkmışlardır.

Bu doğrultuda kat apartmanları inşa edildikleri dönemde konut üretiminde standartlaşma sürecinin teknik belgeleri olarak kabul edilmiştir. Mimarlık ve şehir plancılığı alanlarında mekân niteliklerinin standardize edilmesi arayışları, nitelikli konut üretimini desteklemiştir.

Diğer bir yandan standartlaşma olumsuz bir durum olarak konutlarda değer ve nitelik düşüşlerine neden olmuştur. Standartlaşma ve tipleşme özelliği, 20. yüzyılın ilk yıllarında mimari özellikleri ile statü göstergesi olarak inşa edilen kat

\footnotetext{
${ }^{22}$ Beşiktaş Belediyesi İmar Müdürlü- ${ }^{23}$ Gropius'dan aktaran, Özer, 1965, s. ğü Proje Arşivi.
} 


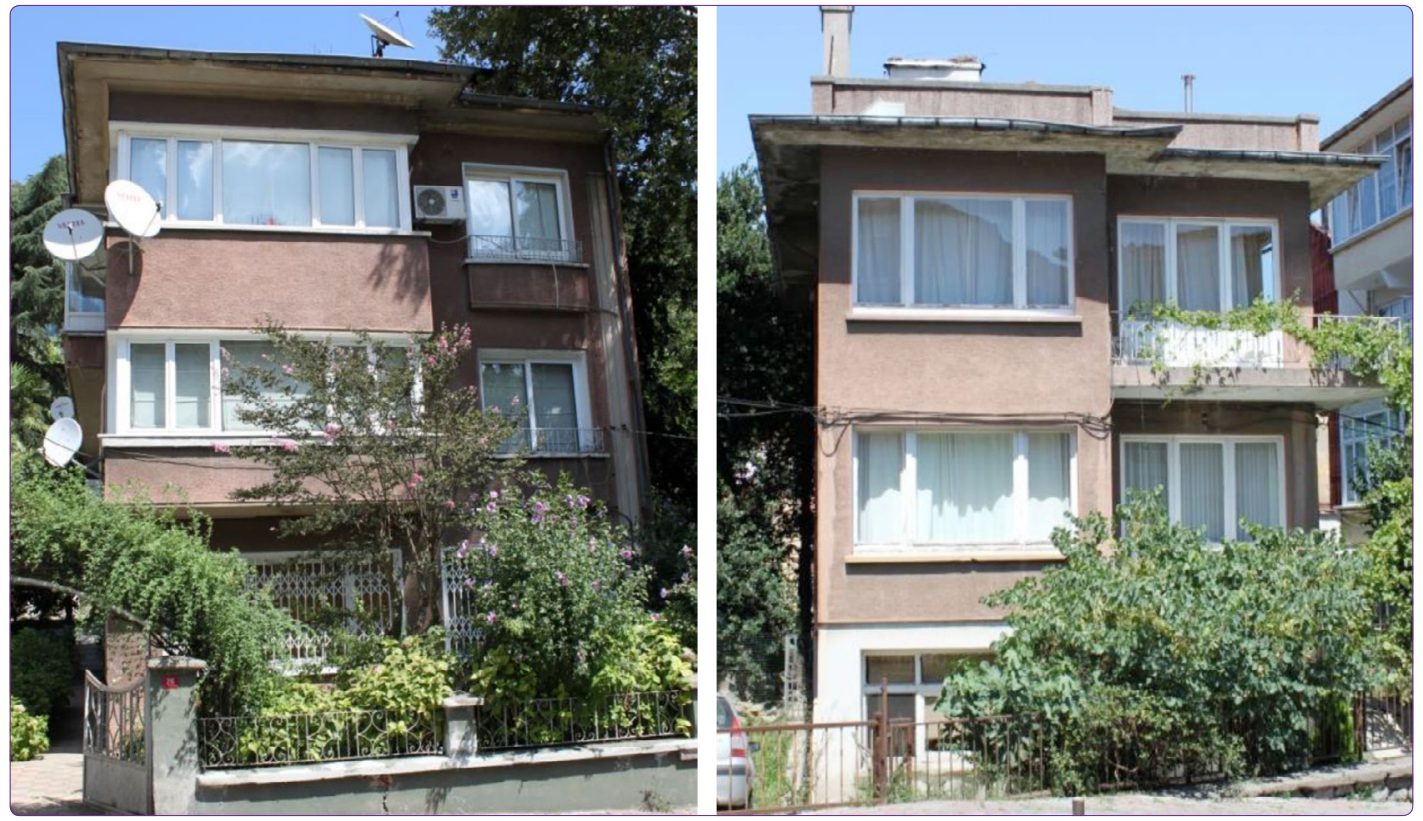

Şekil 6. Benzer parsellerde benzer doluluk boşluk oranları nedeniyle tek tipleşen kat apartmanları. ${ }^{25}$

apartmanlarının, 1950'lerden sonra seri olarak üretilen ticari bir nesneye dönüşmesini beraberinde getirmiştir ${ }^{24}$ (Şekil 6).

\section{Simge Özelliği}

Yapılar ve yerleşim birimleri sosyal ilişkilerin okunabileceği önemli araçlardır. Sosyal ve kültürel yaşam, her zaman mimari yapılar ve yerleşmelerde belirleyici simgeler olmuştur. Konut üretiminin de toplumun sosyo-kültürel yapısından etkilendiği düşünüldüğünde, kat apartmanlarının mimarilerinin, yaptranlarının sosyo-kültürel kimliklerini yansıtma özellikleri olduğu kabul edilmiştir.

Cumhuriyet'in ilk yıllarında üretilen kat apartmanları ve bulundukları alanların, ifade ettikleri ve simgeledikleri anlamlar, koruma özelliklerinin belirlenme sürecinde çok önemlidir. Boğaziçi Bölgesi, Cumhuriyet'le birlikte gelişen modern toplumsal yaşamın geçtiği simge yerleşim alanları olarak kabul edilmiştir. Kat apartmanları da cumhuriyetle birlikte değişen toplumsal hayatın şekillendirdiği konut yaşamının simge yapılardır.

\section{Kişisel Anı Özelliği}

Madran, toplumsal boyutunun olması ve toplum belleğinde bir yeri olması açısından önemli bir anı değeri olan anıtsal yapı ve mekanlar kadar, sıradan yapıların da toplumsal hafizada izler taşıdığını savunmuştur. ${ }^{26}$

Kişilerin psikolojik ve sosyal gereksinimlerinin karşılanması, alışmış oldukları mekan ve yapıların sürekliliği ile doğrudan ilişkilidir. Mekana aidiyet, insan kimliğinin bir parçası olarak sosyal ve psikolojik bir gereksinime bağlı bir oluşumdur. Bu oluşum bireylerin, grupların ya da kültürün gelişimi

\footnotetext{
${ }^{24}$ Cengizkan, 2002, s. 143.

${ }^{25}$ Orhan, Şahan, 2014, s. 258.

${ }^{26}$ Madran, 2009, s. 103.
}

ve korunmasına katkı sağlamakla birlikte, bireylerin kendi yerleşimleriyle kurduğu ilişkiyi de etkilemiştir. Bir yere, eve, mahalleye, şehre, bölgeye ait olduğunu ve o yerinde kendisine ait olduğunu hisseden insanın orayı çok rahat sahipleneceği belirtilmiştir. ${ }^{27}$ Çünkü aidiyet duygusu beraberinde, alışımış varlığa olan bir içtenliği getireceğinden ${ }^{28}$ sahiplenme ve koruma duygusunu kuvvetlendirecektir.

Ülkemizde bazı toplumsal gruplar için kat apartmanlarının bellekte yer etme, belleğin bir parçasını oluşturma özelliği öne çıkmış ve kişisel anı olma özelliği kapsamında değerlendirilmiştir. Yirmi yılı aşan süre boyunca inşa edilmiş kat apartmanları ülkemizde kırkbeş yaş üstü olup, büyük kentlerde doğmuş ve yaşamış nüfusun hemen hemen bütününün anılarında var olan ve hayatında yer etmiş yapılardır. Bu konutlarda doğmuş, büyümüş ve çocukluk anılarını biriktirmişlerdir. Bu nedenle kat apartmanlarının ülkemizde toplumun belirli bir grubunun belleğinde bir yeri ve anısı olduğu kabul edilmiş ve bu açıdan değerli bulunmuştur.

\section{Konut Stoğu Özelliği}

Kat apartmanlarının koruma özellikleri oluşturulurken ekonomik değerleri en önemli özellik olmuştur. Günümüzde daha fazla ekonomik kazanç elde etmek amacıyla yıkılan kat apartmanları, basit müdahalelerle özgün işlevini sürdürebilecek nitelikte yapılardır. Bu bağlamda Boğaziçi'nde konut stoğu olma özellikleri devam eden çok sayıda kat apartmanı tespit edilmiştir. Bu kat apartmanlarının halen toplumun gereksinimlerine cevap veriyor olmaları, basit donanımsal tadilatlarla konut işlevlerini sürdürmeleri, koruma ekonomisinin içindeki rasyonel değerlerinin göstergesi olmuştur.

\footnotetext{
${ }^{27}$ Çekmiş, 2007, s. $155 . \quad{ }^{28}$ Kuban, 2000, s. 82
} 

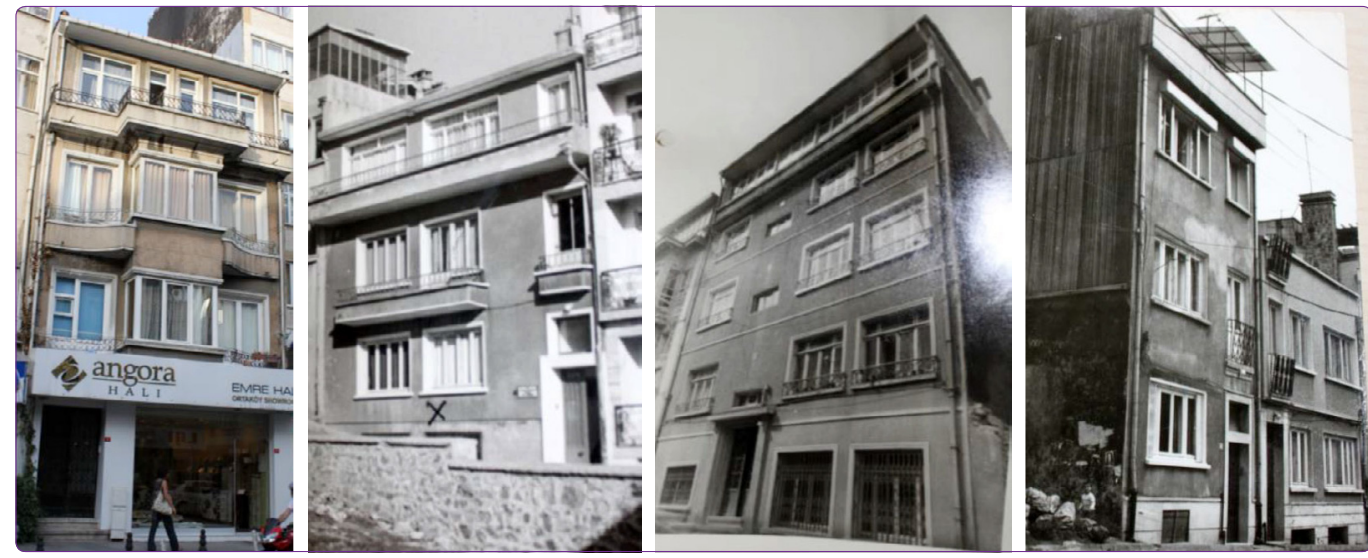

Şekil 7. Bitişik düzende inşa edilmiş kat apartmanları. ${ }^{3}$
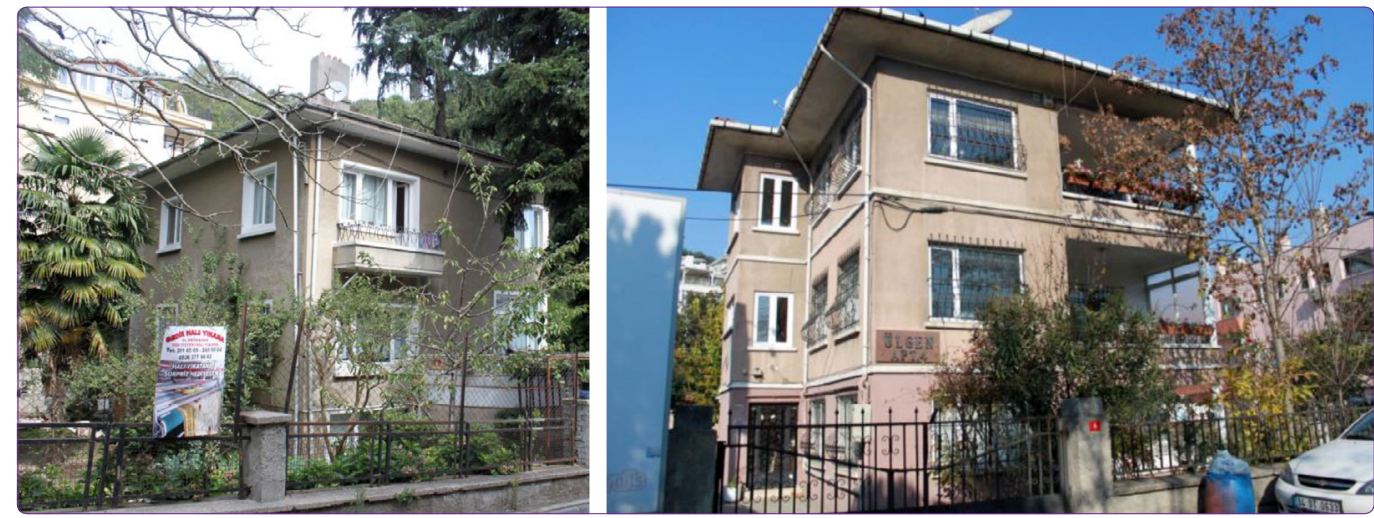

Şekil 8. Boğaziçi'ndeki bahçe içindeki villa görünümlü kat apartmanları. ${ }^{32}$

\section{İşlevsel Özelliği}

Günümüzde mevcut yapıların yeniden işlevlendirilmesi sık başvurulan bir yöntemdir. Madran ve Özgönül'e göre yeniden işlevlendirme ile hem toplumun bir gereksinmesi karşılanmakta, hem de bir yapı işlevsel değeri nedeniyle kullanılarak korunmuş olmaktadır. ${ }^{29}$ Kat apartmanları mümkün olduğu kadar konut olarak kullanılmalıdır. Özgün işlevlerinin devamı öngörülebildiği gibi, özgün işlev değişikliğinin Boğaziçi'nin ve yapıların değerlerini arttıracağı durumlarda kat apartmanlarının farklı kullanımları da düşünülmelidir.

\section{Kimlik Özelliği}

Bir yerleşmeye giren insanın o yerleşmeye ait aklında kalan veriler, yerleşmenin özgün karakterini oluşturmaktadır. $^{30}$ Belirli mekansal ve yapısal özellikler yapı ve mekanları tanımlayan kimlik özelliğidir. Kimlik ihtiyacı, günümüzde birbirini kopyalayan, aynılığın hüküm sürdüğü yerleşmelerin ihtiyaç duyduğu bir özelliktir. Kat apartmanları, bir dönemin konut kimliğinin sürekliliğini sağlayan yapılardır ve korunmaları Boğaziçi Bölgesi'nin kentsel kimliğin sürekliliği açısından önemlidir.

Kat apartmanları ve bulundukları çevreler, Boğaziçi'ndeki konut dokusunun gelişimini günümüze yansıttrlar. 18 .

\footnotetext{
${ }^{29}$ Madran ve Özgönül, 2005, s. $74 . \quad 30$ Özbek, 2007, s. 121.
}

ve 19. yüzyıllarda Boğaziçi'ndeki sayfiye yaşamını yansıtan yerleşim özellikleri, 20.yüzyılın ilk yarısından itibaren kontrolsüz gelişen endüstriyel faaliyetler nedeniyle bozulmaya başlamıştır. Kat apartmanlarının üretilmeye başlanması ile birlikte Boğaziçi, kaybolan konut yerleşim kimliği özelliğini yeniden kazanmış ve tekrar İstanbul'un nitelikli yerleşim alanlarından biri olmuştur.

Boğaz'ın eski yerleşim alanlarında bitişik düzende inşa edilmiş kat apartmanları o dönemin kentsel konutlarıdır. İnşa edildikleri sokakların olanak verdiği boyuttaki cumbaları ve küçük balkonları ile ahşap mimariye benzerlikleri dikkat çekmiştir. İmara açılan yeni yerleşim alanlarında ayrık düzende inşa edilmiş kat apartmanları ise, yeni açılan geniş caddeler ile bunları çevreleyen sokaklarda, bahçe içinde, dönemin yeni mimarlık anlayışına uygun olarak inşa edilmiş, geniş balkon ve terasları olan villa görünümlü yapılardır (Şekil 7 ve 8).

\section{Çevresellik Özelliği}

Korunması gereken yapıların tarihi, sanatsal, mimari vb. değer taşımalarının yanında, içinde bulunduğu yerleşmeyle uyum içerisinde olmaları da önemlidir. Farklı dönemlere ait yapıların uyumlu bir şekilde bir araya gelmesi ile yapılar

\footnotetext{
${ }^{31}$ Boğaziçi İmar Müdürlüğü Proje Arşivi. $\quad{ }^{32}$ Orhan, Şahan, 2014, s. 272.
} 


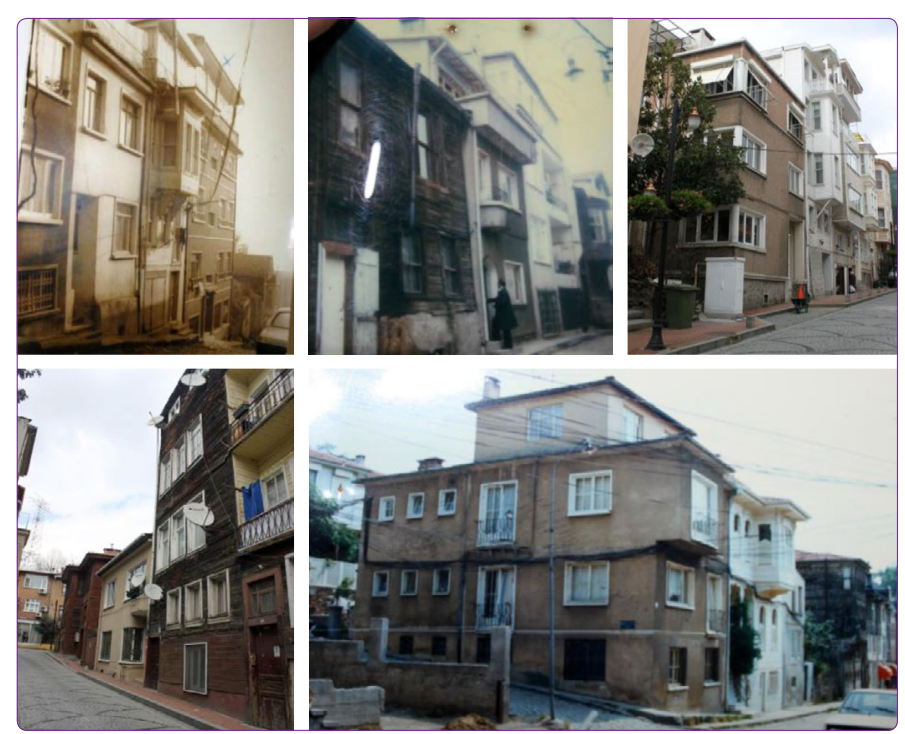

Şekil 9. Kat apartmanlarının ahşap konutlarla birlikte oluşturdukları konut dokusu. ${ }^{35}$

o çevrenin bir parçası olacak ve birbirlerini bütünleyecektir. $^{33}$ Cengizkan, yapıların mevcut yapı, sokak dokusu ve doğal çevreye duyarlı yaklaşımları ile ortaya çıkan biçimsel süreklilik ve uyumunun, çevreye olduğu kadar, onlara tek yapı bazında da değer kazandırdığını belirtmiştir. ${ }^{34}$

$\mathrm{Bu}$ doğrultuda incelendiğinde kat apartmanları ve bulundukları çevreler eski ile yeni arasında biçimsel uyum yakalamış yapılardır (Şekil 9).

Boğaziçi'nde inşa edilmiş kat apartmanları, yakınlarındaki ahşap konutlara attfta bulunan, gabarilerini geçmeyen yükseklik özellikleri, biçimsel benzerlikleri (cumbalar) ile bulundukları sokaklara duyarlı mimari yapıya sahiptirler.

Peyzajları ile Boğaziçi'nin doğal yapısına eklemlenerek bir doku oluşturan konutların çevreyle uyum içinde oluşu önemli bir noktadır. Geniş bahçeler içinde bulunmaları ve peyzaj özellikleri ile az katı kat apartmanları Boğaziçi yerleşiminin kalitesini belirlemiştir.

Kat apartmanlarının Boğaziçi ile bütünleşen ve çevreye değer katan tüm özellikleri, bu yapıların mimari özelliklerini oluşturarak onları bulundukları çevreye ait yapmıştır. Varlıkları ile bulundukları çevreye değer katan kat apartmanları, Boğaziçi'nin yıllardan beri devam eden kaliteli konut alanı özelliğini sürdürmesine katkı sağlamıştr.

\section{Grup, Çokluk ve Homojenlik Özelliği}

Madran ve Özgönül'e göre grup özelliği, kültür varlıklarının bir arada bulunmasından kaynaklanan bir değer olarak tanımlanmıştr. ${ }^{36}$ Bu yapıların bir arada bulunmaları tek başlarına sahip oldukları tekil mimari değerden daha önemlidir. Planlı bölgelerde aynı anda belirli kurallara uygun olarak inşa edilmiş kat apartmanlarının inşaat süreci,

\footnotetext{
${ }^{33}$ Madran ve Özgönül, 2005, $85 . \quad{ }^{35}$ Boğaziçi İmar Müdürlüğü Proje Arşivi.

${ }^{34}$ Cengizkan, 2005, s. $15 . \quad{ }^{36}$ Madran ve Özgönül, 2005, s. 70.
}

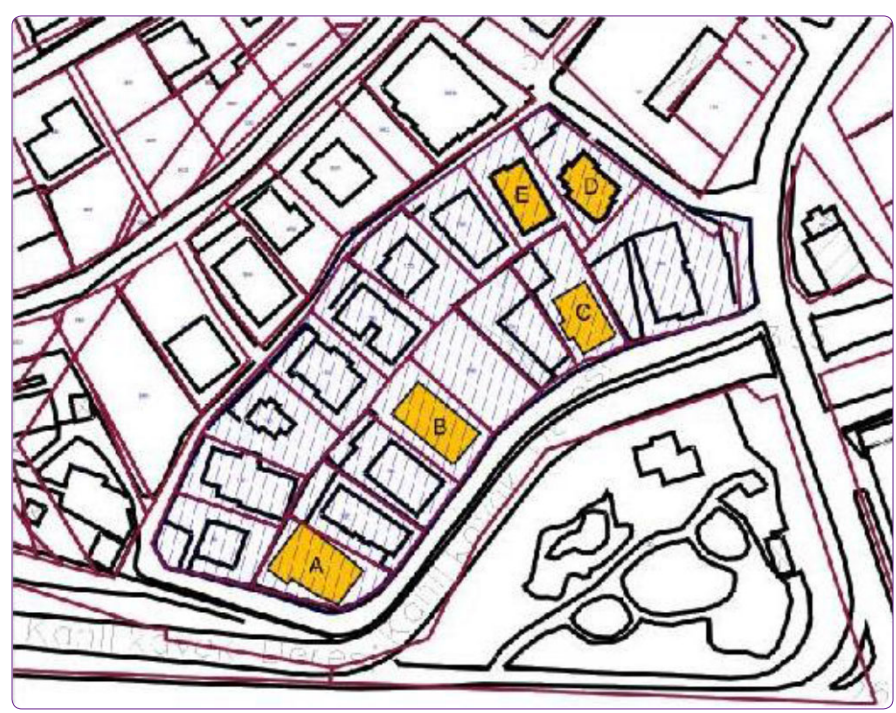

Şekil 10. Baltalimanı́nda grup değeri olan konut adasına ait halihazır durum. ${ }^{37}$
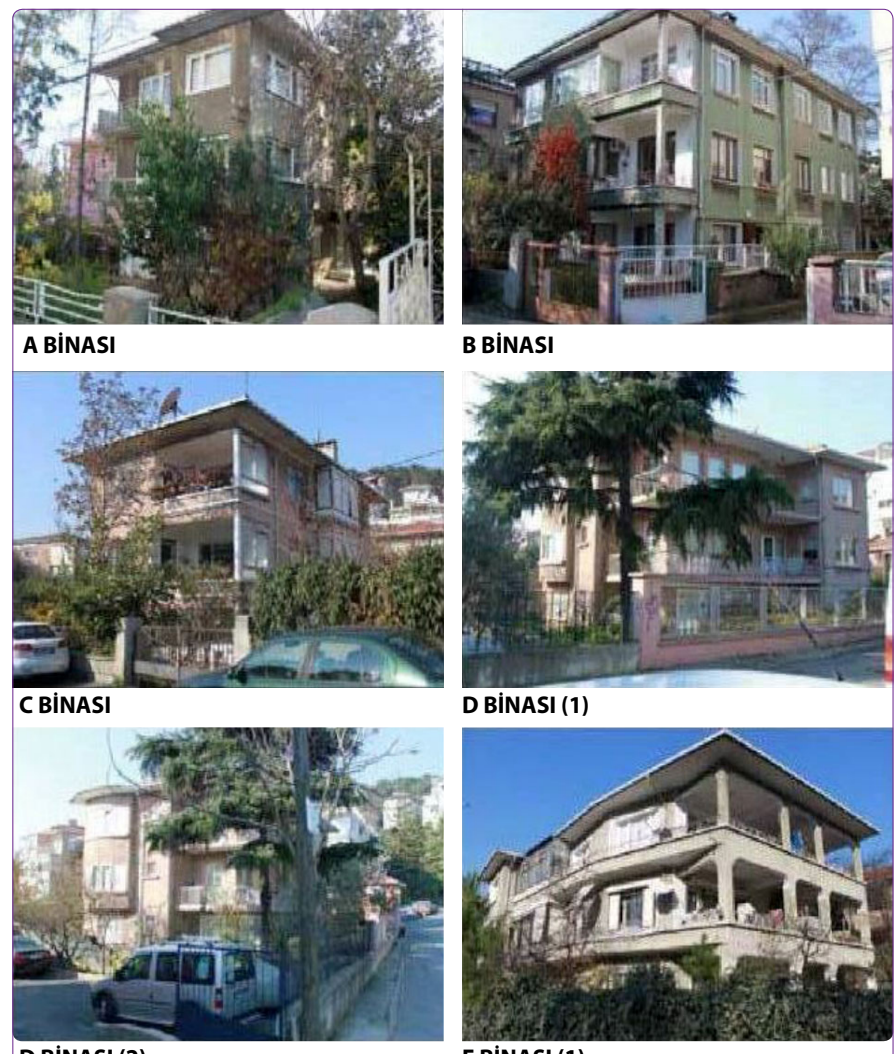

B BINASI
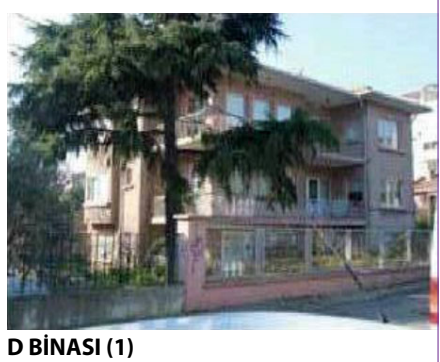

D BINASI (2)

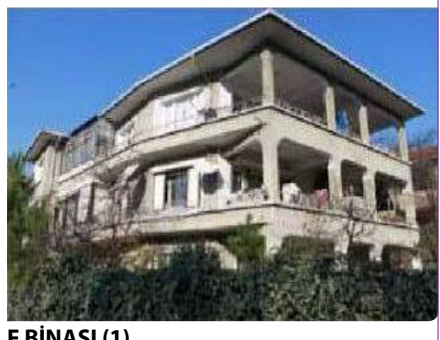

Şekil 11. Baltalimanı'nda grup değeri olan konut adasında bulunan kat apartmanlarına ait fotoğraflar. ${ }^{38}$

aynı zamanda bölgenin planlama sürecini belgelemektedir (Şekil 10-13).

Çokluk özelliği; belli bir yapı türünün, tanımlanmış bir alanda, coğrafi bölgede ya da ülkedeki sayısı ile ilgilidir. Bu değerin teklik ve enderlik değeri ile çeliştiği belirtilmiştir.

${ }^{37}$ Orhan, Şahan, 2014, 277.

${ }^{38}$ Orhan, Şahan, 2014, 277 


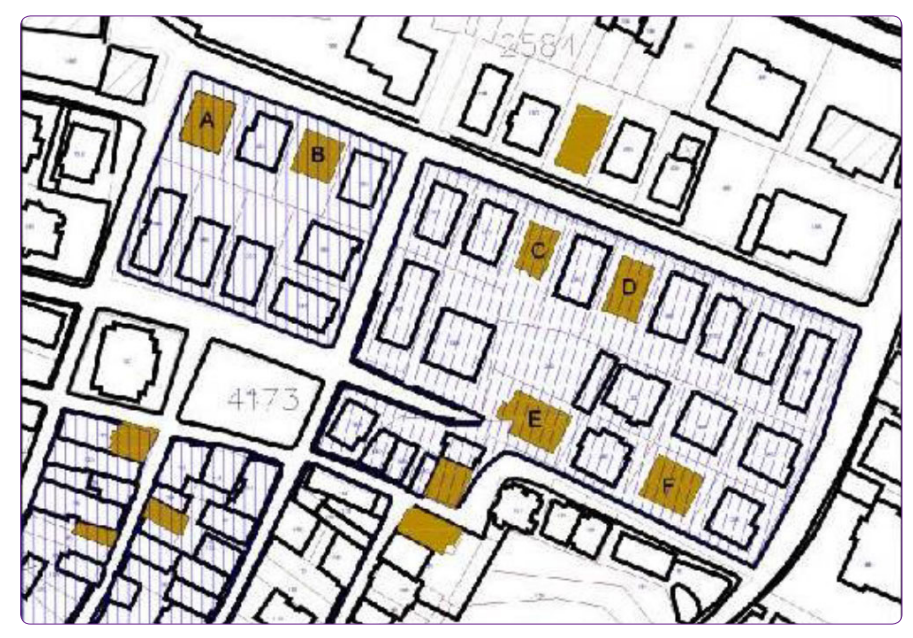

Şekil 12. Emirgan'da grup değeri olan konut adalarına ait halihazır durum.
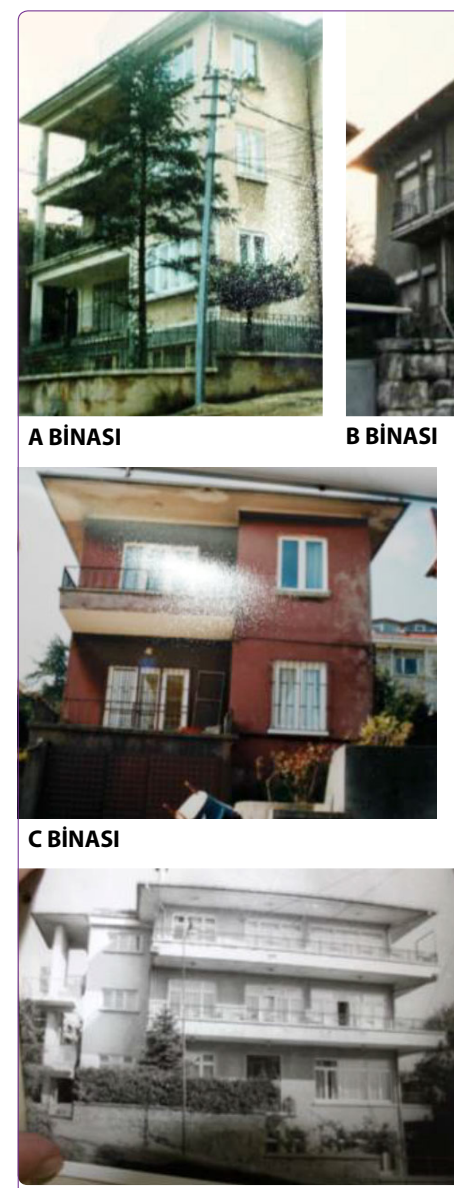

E BINASI
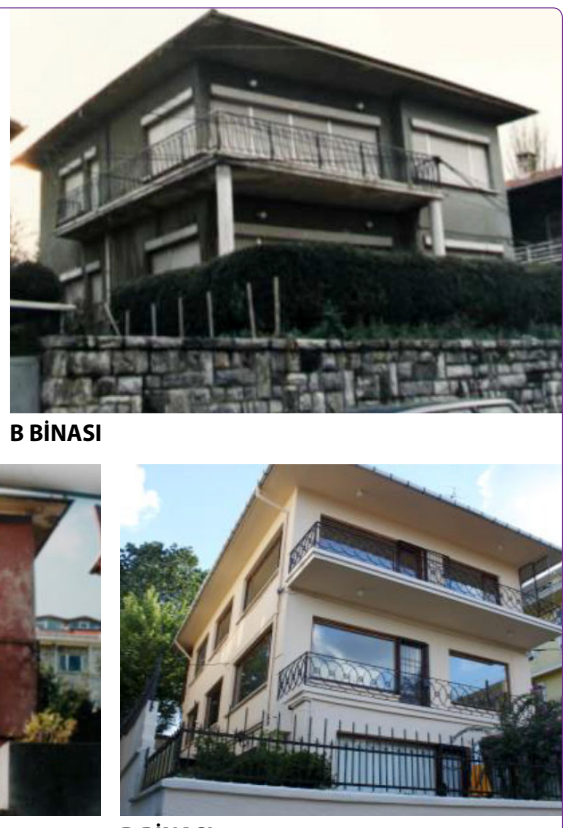

D BINASI

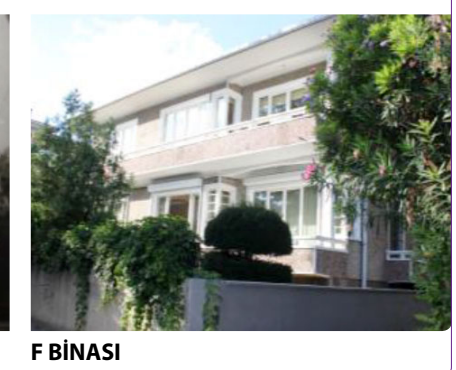

Şekil 13. Emirgan'da grup değeri olan konut adasında bulunan kat apartmanlarına ait fotoğraflar..$^{40}$

Çok rastlanan bir kültür varlığı türü ya da yapım tekniği, o bölgenin ya da tarihsel dönemin tipik yapısı olarak ayrı bir önem kazanmıştır. Çokluk değerinin sayısal karşılığının ta-

\footnotetext{
${ }^{39}$ Orhan, Şahan, 2014, 277.
}

${ }^{40}$ Orhan, Şahan, 2014, 277.
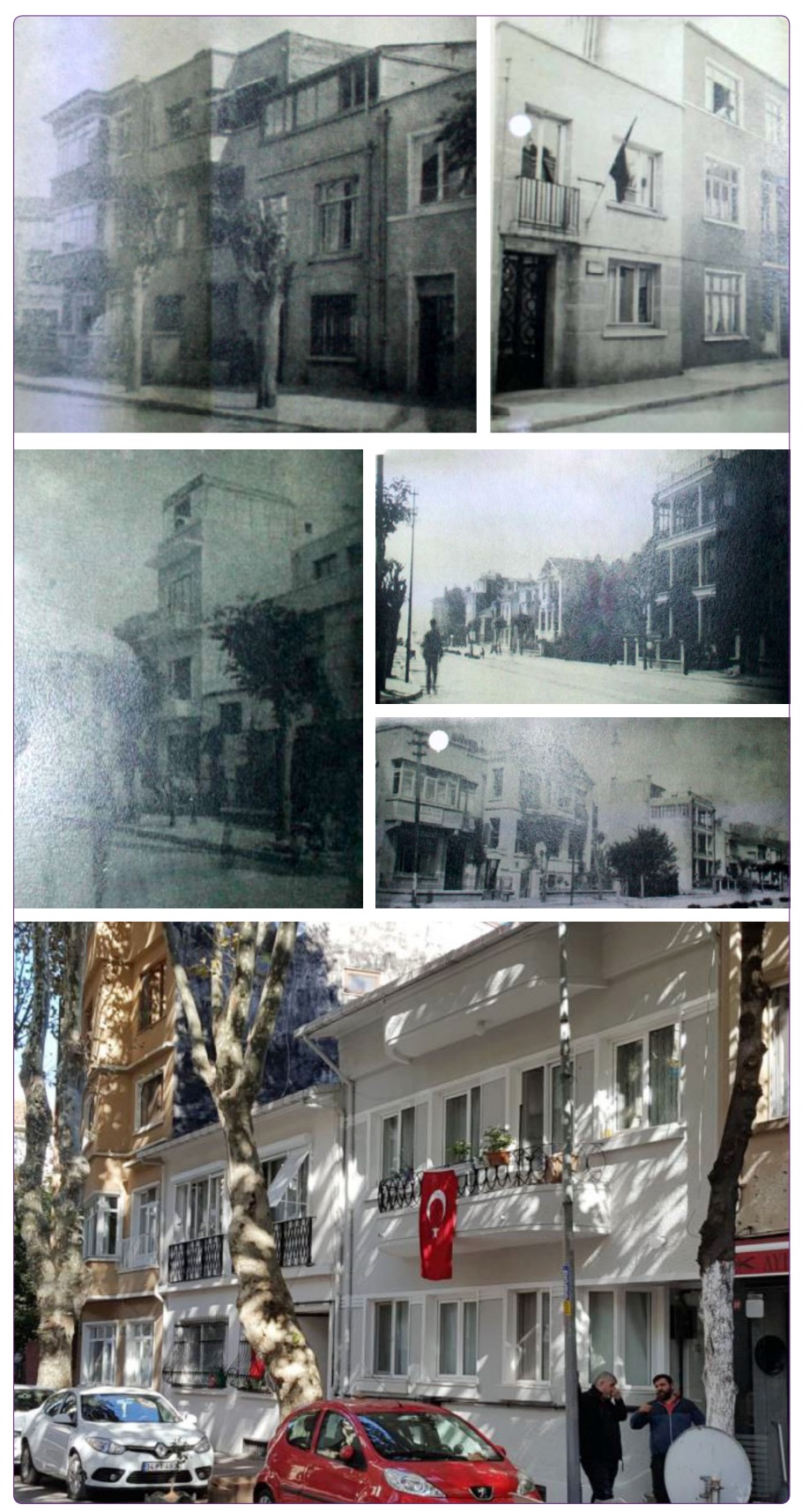

Şekil 14. Kat apartmanlarının bir arada yoğun olarak bulunduğu alanlar. $^{42}$

nımlanamayacağı belirtilmiştir. Bir alanda ya da zaman diliminde, diğer yapı türü veya elemanlarla karşılaştırıldığında çoğunlukta olan yapılar ya da elemanların çokluk değeri olacağı belirtilmiştir. ${ }^{41}$ Bugün Boğaziçi'nin Avrupa Sahili'ndeki mevcut konut sayısına baktığımızda, tespit edilen 190 yapı (sadece günümüze ulaşan), kat apartmanlarının çokluk değerleri olduğunu söylemek için yeterli olmamakla birlikte, inşa edildikleri dönemdeki toplam konut sayısı düşünüldüğünde, kat apartmanlarının bu değeri taşıdıkları söylenebilir.

${ }^{41}$ Madran ve Özgönül, 2005, s. 71.

${ }^{42}$ Boğaziçi İmar Müdürlüğü Proje Ar- 
Homojen özelliği, bir alan içindeki yapı, parsel, sokak, meydan vb, ölçeklerdeki değerlerin eşit sayı ve nitelikte dağılmış olmaları ile ilgilidir. Avrupa Mimari Mirası'nın Korunması sözleşmesinde (Recommendaiton R(91) 13 on The Protection of The Twentieth Century Architectural Heritage, COE-1991); bir alanın korunması için homojen olma kavramı önemli bir özellik olarak kabul edilmiştir. ${ }^{43}$

Boğaziçi'nin Avrupa Sahili'nde tespit edilen kat apartmanlarından her yapı adasında ortalama 2-3 adet tespit edilmiş olup, her mahallenin en büyük cadde veya sokaklarında yan yana yer almaktadır. Bu nedenle kat apartmanlarının homojen değerleri vardır (Şekil 14).

\section{Değerlendirme ve Sonuç}

1946-1966 yılları arasında Boğaziçi'nde üretilmiş kat apartmanlarının üretim ve kullanım süreci sosyo-kültürel, siyasi, ekonomik, mimari ve teknik açıdan değerlendirildiğinde bu yapılar özelinde aşağıdaki sonuçlara ulaşılmıştır.

- Farklı görünüşleri, mimari biçimleri, üslupları, bu yapıların üretildiği dönemde toplumda bireyler arasındaki sosyo-kültürel farklılık ve çeşitliliğe bağlıdır ve bu anlamda yeni estetik değerleri vardır.

- Avrupa'da uygulanmış yapılarla biçim, teknoloji, malzeme ve mimari yaklaşım açısından benzer nitelikte üretilmiş, inşaat kalitesi yüksek yapılardır. Dünyada ve Avrupa'da gelişen evrensel ve yerel mimari anlayışın ülkemizdeki örnekleri olmaları açısından önemli ve değerlidirler.

- Hepsi mimarlar tarafindan tasarlanmıştır. Tasarımın ve tasarımcının uğraş alanı içinde olması gerektiğinin bilincinin topluma yerleşmesi ile ortaya çıkmış nitelikli konutlardır.

- Tek parselde mülkiyet bölünmesine imkan veren hukuksal düzenlemelerin uygulanmaya başlamasıyla üretilmiş, mülkiyet hukukundaki değişim sürecini belgeleyen yapılardır.

- Yapı üretim süreci ve teknolojisinin farklılaşmasının belgeleridir. Bir dönem üretilmiş ve yok olmuş bir yapı türünün kalan örnekleridir ve yapıldığı teknik bugün terk edilmiştir.

- 20. yüzyılın değişen aile ve toplumsal yaşamının, sosyo-kültürel, ekonomik ve siyasi etkilerinin kentsel mekana yansımasının belgeleridir.Bulundukları çevreler, toplumun sosyal yaşamını yansıtması açısından tarihi ve kültürel katmanlılık özelliğine sahiptir.

- Yeni yaşama dahil olmanın göstergeleri olmaları açısından talep edilmişlerdir. Üretildikleri dönemde kentlerin görünümünde, insanların hafiza ve anılarında dönemin yeni konut yapıları olarak yer etmişlerdir. Kent silüetinde gelenekselin yerini alan dönemin popüler konut üretiminin simge yapılarıdır.

\footnotetext{
${ }^{43}$ Madran ve Özgönül, 2005, s. 71
}

- Günlük yaşamın sürekliliğinin bir parçası ve kullanılabilir konut stoğu olarak önemli ekonomik değerlerdir.

- Halen özgün fonksiyonları ile kullanılmaları nedeniyle güncel konut stoğu olma potansiyelleri sürmektedir ve Boğaziçi'ndeki konumları açısından farklı şekillerde işlevlendirme olanakları vardır.

- Kütle-gabarileri, doluluk boşluk oranları açısından geleneksel ahşap konut dokusu ile uyumlu, Boğaziçi silüetine saygılı yapılardır. Mimari ve yapısal özellikleri ile bulundukları çevreye değer katan kat apartmanları, Boğaziçi'nin yıllardan beri devam eden sadece kısa bir dönem kesintiye uğrayan nitelikli konut alanı özelliğini sürdürmesine katkı sağlamışlardır.

Boğaziçi'ndeki kat apartmanları rant nedeniyle günümüzde çok hızlı bir değişim süreci içindedir. Ülkemizdeki 20. yüzyıl mimarlık mirasının belirlenmesi ile ilgili çalışmalar incelendiğinde, kat apartmanlarının özelliklerinin mevcut koruma değerlerine uymadığı ve korunmaları ile ilgili önemli sıkıntılar olduğu açıktır. Koruma uzmanlarının bile bu miras ile ilgili birbirinden farklı görüşleri vardır. Kat apartmanları hakkında daha çok bilimsel çalışmaların hazırlanması ve dikkatlerin bu yapılara çekilmesi önemlidir. Bu yapıların nitelikli örneklerinin acilen korumayla ilgili yasal düzenlemeler kapsamına alınıp, kültür varlığı olarak tanımlanması zorunludur.

\section{Kaynaklar}

10/12/1987 tarihli Korunması Gerekli Taşınmaz Kültür ve Tabiat Varlıkları'nın Tespit ve Tescili Hakkında Yönetmelik.http:// www.resmigazete.gov.tr/eskiler/2012/03/20120313-6.htm

13/03/2012 tarihli Korunması Gerekli Taşınmaz Kültür Varlıklarının ve Sitlerin Tespit ve Tescili Hakkında Yönetmelik http:// teftis.kulturturizm.gov.tr/TR-14660/korunmasi-gereklitasinmaz-kultur-varliklarinin-ve-sitl-.html

1983 tarih, 2960 sayılı Boğaziçi Kanunuhttp//www.mevzuat.gov. tr./MevzuatMetin/1.5.2960.pdf.

2863 Sayılı Kültür ve Tabiat Varlıkları'nı Koruma Kanunu. http:// www.mevzuat.gov.tr/Metin.Aspx?MevzuatKod=1.5.2863\&M evzuatlliski=0\&sourceXmISearch

Balamir A. ve Asatekin G., (1991). “ Ulusal Kimlik Sorusu Üzerine Karşıt Düşünceler ve Konut Mimarisi”, ODTÜ MFD, 11(1-2): s. 73-87.

Batur, A., (1998). "1925-1950 Döneminde Türkiye Mimarlığı": 209-234; Derleyen: Sey, Y., 75. Yılda Değişen Kent ve Mimarlık, Tarih Vakfi, İstanbul.

Beşiktaş Belediye Müdürlüğü Arşivi.

Boğaziçi İmar Müdürlüğü Proje Arşivi.

Bozdoğan, S., (2002). Modernizm ve Ulusun İnşaası. Erken Cumhuriyet Türkiye'sinde Mimari Kültür, Metis Yayınlar, İstanbul.

Cengizkan, A., (2002). "Yabancılaşma Nesnesi Olarak Banyo: Modernizm, Tüketim Toplumu ve Banyo Kültürü", Modernin Saati, 20. yy.'da Modernleşme ve Demokratikleşme Pratiğinde Mimarlar, Kamusal Mekanlar ve Konut Mimarlığı içinde, 1. Baskı, Eylül 2002, Ankara Mimarlar Derneği Yayın No:9, Boyut Yayın Grubu, Ankara, s. 143-155. 
Cengizkan, A., (2004). “Özgünlük ve Tekrarın Tekrarı: Konutta Yeni Gelişmeler ve Nesne Olarak Konut", Arredamento Mimarlık, s. 106-115.

Cengizkan, A., (2005). "Gelenek, İşlev, Moda: Süreklilikler ve Kopuşlar", Gelenek İşlev ve Moda Arasında Günümüz Konut Kültürü, 13 Nisan 2004, TMMOB Mimarlar Odası Yayını, Ankara, s. 11-22.

Cengizkan, A., (2011). Koruma Kültürümüzün Değerler Sistemini Değiştirmek ve Yapı Türleri, Cumhuriyet'in Mimarlık Mirası Sempozyumu, 26-27 Şubat 2009, TMMOB Mimarlar Odası Yayını, 1. Baskı, Ankara, s. 117-121.

Çekmiş, A.,vd., (2007). "Sürdürülebilir Konut ve Kent İçin Kültürel Kapital", Kent, Kültür, Konut" IAPS-CSBE Network Kültür ve Mekan Toplantıları, Birinci Ulusal Sempozyum, İstanbul 14-16 Aralık; Derleyen: Yıldız, T., H. ve Eyüce, A., (2010). Bahçeşehir Üniversitesi Yayınları,s.152-158.

Ergut, A., E., (2011). Cumhuriyet Mimarlığını Yaratanlar, Cumhuriyet'in Mimarlık Mirası Sempozyumu, 26-27 Şubat 2009, TMMOB Mimarlar Odası Yayını, 1. Baskı, Ankara, s. 113-116.

Gökan, K., Yıldırım, S., Bostancıoğlu, E., Kasapoğlu, E., Düzgün, E., Öztürk, Ç., A., Uluca, E., Enginöz, E., (2001). "Yer-el ve Evrensel'in Diyalektiği", Uluslararası XIII. Yapı ve Yaşam Kongresi, 20. Yüzyıl Mimari Mirası, Bursa, s. 31-43.

Hamamcıoğlu, M., (2001), "İzmir Mimar Kemalettin Caddesi'ndeki Yirminci Yüzyıl Binalarının Değerlendirilmesinde Ölçüt Sorunu", Uluslar arası XIII. Yapı ve Yaşam Kongresi, 20. yüzyıl Mimari Mirası, Bursa, s. 112-120.

Kuban, D., (2000). Tarihi Çevre Korumanın Mimarlık Boyutu Kuram ve Uygulama, YEM Yayınları, İstanbul.

Madran, E., (2009). “Cumhuriyet Dönemi Mimarlık Yapıtlarının Taşıdıkları Değerler”, TMMOB Mimarlar Odası Kültürel Mirasın Korunması Komitesi, Kastamonu 19-20 Mayıs 2007, s. 101-104; Derleyen: TMMOBKYK, (2009). Cumhuriyet Dönemi Mimari Mirasının Korunması/Korumada Yeni Tanımlar Kavramlar içinde, Mimarlar Odası Yayınları, Ankara.

Madran, E., ve Özgönül, N. (2005). Kültürel ve Doğal Değerlerin Korunması, 1. Baskı, TMMOB Yayınları, İstanbul.

Orhan, Şahan, A.,(2014). Boğaziçi'nin Avrupa Sahili'nde 19461966 Yılları Arasında İnşa Edilmiş Kat Apartmanlarının Koruma Öncelikleri Açısından Değerlendirilmesi”, Doktora Tezi, Yıldız Teknik Üniversitesi, Fen Bilimleri Enstitüsü, İstanbul.

Özbek, Ö., M., (2007). “Geleneksel ve Modern Yerleşmeler Bağlamında, Mekan Olgusu ve Barındırdıkları Kültürel Altyapılar", s. 116-122; Derleyen: Yıldız, T., H. ve Eyüce A., Kent, Kültür, Konut: IAPS-CSBE Network Kültür ve Mekan Toplantiları, 1.Ulusal Sempozyum, İstanbul 14-16 Aralık 2010, Bahçeşehir Üniversitesi Yayınları, İstanbul.

Özer, B., (1965). Rejyonalizm, Üniversalizm ve Çağdaş Mimarimiz Üzerine Bir Deneme, Doktora Tezi, iTü Mimarlık Fakültesi, İstanbul.

Polat, O. E. E., (2008). Modern Mimarlık Mirasının Korunması: Kuram ve Yöntem Bağlamında Bir Değerlendirme, Doktora Tezi, Y.T.Ü. Fen Bilimleri Enstitüsü, İstanbul. 